\title{
MARKETINGKLASSZIFIKÁCIÓ VS. MARKETINGKONTINUUM
}

\author{
KORREFERÁTUM PISKÓTI ISTVÁN „A BUSINESS MARKETING \\ IDENTITÁSA - ELMÉLETI, KUTATÁSI TRENDEK, AZ INNOVÁCIÓ- \\ VEZÉRELT MODELL" CÍMUÚ TANULMÁNYÁHOZ
}

Egy tudományterület lehatárolása nem lehetséges klasszifikációk - helyenként dichotómiák - konstruálása és differentia specifica-k meghatározása nélküil. Emellett számos esetben kontinuumjelleggel pontosabban tudjuk leírni a marketingkategóriák egymáshoz képesti viszonyát. Erre a lehatárolásra tesz kísérletet Piskóti István saját kutatási eredményeket is felsorakoztató tanulmánya.

\section{Kulcsszavak: klasszifikáció, differentia specifica, dichotómia, kontinuum, modellek}

A jelenségek tudományos igényú leírása szükségszerû egyszerúsítéseken és kategorizálásokon keresztül történik. Minden tudományos modell arra törekszik, hogy - a validitás elérhetó maximuma mellett - kódolt kategóriákkal vonjon össze olyan elemeket, amelyek egyébként még tartalmaznak egyedi sajátosságokat. Az összevonás kritériuma az adott kategórián belüli heterogenitás már elfogadható mértéke. Amikor a kategorizálás a tudományterület különböző irányait modellezi, akkor azt figyelhetjük meg, hogy az adott tudományterület fejlődése az, ami igényli a vizsgálati területek lehatárolását.

Így történik ez a marketingtudomány területén is. És a tudományterület kutatási céljainak osztályozása mellett előbb-utóbb önmaga klasszifikációját is elkezdi. Tulajdonképpen a tudományos vizsgálati irányok diverzifikálódása jelenik meg ebben a kategorizálási törekvésben. Amellett ugyanis, hogy a tudományterület egysége szükségszerű, a fejlődés során egyre több olyan eredmény halmozódik fel, ami szignifikánsan eltéró jegyeket mutat egy másik irányhoz képest.

Piskóti István tanulmánya jól mutatja be a marketing- és közelebbről a business marketing klasszifikáció történetiségét, továbbá a különböző párhuzamos definíciós eltéréseket. További példaként megemlíthetjük Daniel Michel, Robert Salle és Jean-Paul Valla „Marketing industriel” címú könyvét (1996), amely az ipari marketing és a B2B-marketing közé egyenlőségjelet tesz, továbbá azt a szervezetközi marketing egy alrendszerének tartja (61. o.). Nem kis képzavarral a könyv projektmarketing fejezete a $\mathrm{B} 2 \mathrm{G}$ piacra helyezi az ipari marketinget. Sokkal világosabban fogalmaz a már klasszikusnak számító Gross - Banting - Meredith - Ford-féle 1993-as Business Marketing szakkönyv: „,....a business marketing terminus megfelelőbb, mint az ipari marketing, mert például egy sampongyártó és nagy-, illetve kiskereskedő vevőinek esetében sem okoz félreértést" (6. o.). Más kérdés, hogy ez a mú még nem szakít a téma hagyományos 4 P-alapú feldolgozásával.

A kategorizálás helyenként extrém formákat ölt. Ilyen fejlemény volt az Industrial Marketing \& Purchasing Group (IMP) megjelenése és a mainstream marketingtudománytól markánsan eltérő önmeghatározása. Abban az időben az IMP-terminológia és módszertan csak egy szúkebb szakmai kör által volt ismert. Hozzá kell tenni, hogy az Egyesült Államok marketingkutatói hosszú ideig ignorálták az IMP-iskolát. Nem abból kiindulva, hogy minden marketinginnovációnak a marketing óshazájából kell elindulnia világhódító útjára, hanem azzal a szakmai érveléssel, hogy az esetalapú, kvalitatív jellegú kutatásmódszertan nem alkalmas a reprezentatív általánosításra. Az is korlátozta a közeledést, hogy az IMP nyelvezete, fogalomhasználata jelentôsen eltért a hagyományostól. A terminológiai különbségeket nem sikerült a kommunikációban áthidalni. Mindenesetre az IMP képes volt a túlélésre, és kutatók százait vonta be egy új módszertani megközelítésbe. Közel 25 éves munkával azt is elérte, hogy néhány eret- 
nek amerikai is csatlakozott a kutatási programokhoz. A Piskóti István által is idézett Shelby Hunt (2013) éppen az amerikai értékteremtési iskola (Value Delivery Framwork) és az IMP interakciós elméletének szintézisére építi a saját általános B2B elméletét. Az IMP-iskola jelentôsége kiemelkedő, hiszen számos új koncepciót és modellt tudott beépíteni a marketingtudományba ${ }^{1}$.

A gazdag és rendkívül heterogén forráselózmények alapján meglehetősen zavarba ejtő kérdés, hogy mi a business marketing abszolút differentia specifica-ja? Merthogy - Piskóti István tanulmánya is ezt erósíti meg - azt szerzóje válogatja. Hogy jelen korreferátum szerzője is hozzájáruljon a definíciós kavalkádhoz, első megközelítésben az alábbiak túnnek ilyennek:

- a vevó nem laikus, következésképpen kisebb a diádban a kompetencia aszimmetria,

- a származtatott kereslet,

- a funkcionális motivációból következő racionális döntéshozatal,

- a partnerek kölcsönös függése.

Amennyiben közelebbról megvizsgáljuk a fenti tényezőket, a kép sokkal árnyaltabb. A kompetencia az aktorok diadikus viszonyában többféleképpen is értelmezhetón. Az aktorok észlelt bizonytalansága felértékeli a vélt kompetenciák szerepét a kapcsolatban. A szállító által tudatosan fejlesztett kompetenciaimázs a vélt szállítói kompetencia alapja. Érdekes lehet annak feltárása, hogy a szolgáltatást igénybe vevő vajon a „,szolgáltató kompetens voltát" ítéli-e meg, vagy inkább a szolgáltatásról szóló kommunikációba rejtett kompetenciákat? A tranzakció elején valószínú, hogy inkább a kommunikációba rejtett kompetenciák és közvetett információk (mint a referenciák) alapján ítéli meg a kockázatokat, míg a szolgáltatás igénybevétele során (illetve után) a kommunikáció kisebb - jóllehet nem elhanyagolható - jelentôséggel bír. Visszatérve arra, hogy itt a vevő nem laikus, a szituáció arra csábítja, hogy felülértékelve saját kompetenciáját a valósnál erősebb alkupozícióba helyezkedjen. Vagyis a vélt kompetenciaaszimmetria a diád két oldalán nem azonos mértékú. Ezt kell a szállítónak ügyfélorientált módon kezelnie. Ahogy Piskóti István fogalmaz: „...a vevő gyakran szubjektív, a képességei korlátai által nem mindig kellóen körültekintően, megalapozottan kialakított elvárásainak kell megfelelni..."

A származtatott kereslet és a racionálisabb döntéshozatal valóban differentia specifica - jóllehet utóbbira egyes fogyasztói magatartási szegmensekben is van példa -, a kölcsönös függés azonban sokkal inkább jószág- mint piactípus függvénye. Nem véletlen, hogy a kapcsolati marketing eredetileg a fogyasztói szolgáltatások elméletében jelent meg (Gummesson, 1995).
A fentieket kiegészítve a business marketing természetes jellemzője még, hogy a vevő minden esetben valamilyen szervezet (vállalat, intézmény, kormányszerv stb.). További fontos sajátosság, amely összefüggésbe hozható a vevő (többé-kevésbé) professzionális magatartásával, a technológia szerepe, amely valamilyen mértékben minden szervezetközi üzleti kapcsolatban megjelenik. A szakirodalom emellett még számos megkülönböztető jellemzőt nevez meg. Ezekről azonban viszonylag könnyú kimutatni, hogy egyik sem abszolút differentia specifica. Ilyeneket Piskóti István is bemutat: korlátozott számú piaci szereplő, merev időbeli kereslet, a vevók problémamegoldást keresnek, kompetenciák által megalapozott ígéretet adunk el, nemzetközileg nyitott piac stb. Fentiek közül szinte mindegyik kimutatható a fogyasztói piacon is, de különösen a problémamegoldás és a kompetencia meghatározó szerepe olyan, ami nem business piaci sajátosság. Már a mainstream marketing is a vevő problémájának megoldásából indul ki, a vélt vagy észlelt kompetencia pedig legkésőbb a Vargo-Lusch-féle Service Dominant Logic modellben (2004) megjelent, mint egy általános értékkategória. A tranzakció sikere alapjában a megbízott és a megbízó kompetenciáin múlik (Piskótinál ez a versenypotenciál eleme). Ahogy az SDL-tézis fogalmaz: A versenyelőnyt a kompetenciák biztosítják.

\section{Poláris kettéosztás}

A klasszifikációs törekvések sorsa gyakran az, hogy dichotómiákká alakulnak át, a dichotómia polárisan kettéosztásos értelmében. A marketingklasszifikációk között is vannak ilyenek: fogyasztói vs. szervezeti piacok, tranzakciós vs. kapcsolati marketing, csatorna vs. network, vevőorientáció vs. kreatív marketing, hard selling vs. soft selling. Ezek között emlékezzünk meg Klaus Backhaus ipari marketing dichotómiájáról. Egy még a 80-as években publikált „Investitionsgüter-Marketing” (Backhaus, 1982) címú múvében rendkívül találóan alkalmazza az Individualtransaktionen vs. Routinetransaktionen dichotómiát. Jómagam ezt a klasszifikációt azért tartom szerencsésnek, mert a termelőeszköz-piacon a projektszerú beszerzések és a rutinjellegú vásárlások valóban szignifikáns eltéréseket mutatnak. Mintegy tükörképe a fogyasztói piacon az FMCG vs. tartós fogyasztási cikk dichotómiának. Megjegyzendő, az Investitionsgüter-Marketing kategóriát Backhaus a Konsumgüter-Marketing-gel szemben határozza meg.

A poláris kettéosztás a klasszifikáció egyik olyan formája, amely egyszerúségénél fogva jól szemlélteti az egymást kizáró, dichotóm jellegú kategóriákat. Jóllehet éppen egyszerúségében rejlik a veszélye, a tudományos 
klasszifikáció kedvelt módszere. Gyengesége akkor túnik ki, amikor átmeneti fogalmakat vagy jelenségeket kell ennek alapján osztályozni. Egyik tipikus példája a marketingben a fizikai és a nem-megfogható jószágok dichotóm felfogása ú.m. termék vs. szolgáltatás. Ebben a keretben ugyanis nem lehet eldönteni, hogy például egy klasszikus éttermi szolgáltatás alapkategóriája a megfogható ételkínálat vagy a nem-megfogható atmoszféra. Ezzel el is jutottunk a címben jelzett kontinuum fogalomhoz.

\section{A marketingkontinuum}

A klasszifikációs megoldások ellentmondásait tehát időnként a kontinuumjellegú konstrukció tudja feloldani. A marketingtudományban is vannak ilyen kísérletek. Ilyen például a vizsgálati-tapasztalati-bizalmi jószágkontinuum modell, amely jól használható a szakterület oktatásában. Empirikus alátámasztása amiatt korlátozott, hogy a három kategória átfedéseit nem tudja kezelni. Mindazonáltal az egyszerú jószágklasszifikációknál közelebb áll a fogyasztó nézőpontjához.

A business marketingben is elképzelhető ilyen kontinuumok konstruálása. Így például a B2B lehatárolás helyett új tudományos eredményeket hozhat a B2BB2G kontinuum, annak kifejezésére, hogy például az építés-szerelési üzletágban a termelő-felhasználó és az állami vevő magatartása között az átmenet folytonos. A francia projektmarketing-iskola (Robert Salle, Bernard Cova és mások) ezért következetesen együtt tárgyalja a két vevőtípust (lásd például: Cova - Salle, 1999). Backhaus fent hivatkozott egyedi vs. rutinügyletek dichotómiája is jobban értelmezhetô lenne egy kontinuum keretben. A projektek egyedisége ugyanis különböző mértékú lehet, például attól függő́en, hogy első vagy ismételt beszerzésról van szó. Minden projektben vannak újszerú, tehát egyedi elemek, de az ismétlődés, azaz a rutinjelleg sem zárható ki.

Hasonlóképpen kontinuumjellegû a tranzakciós és kapcsolati orientáció. Bármennyire is logikusnak túnik a tartós ügyfélkapcsolatok gazdasági előnye az új ügyfelekkel szemben, ezt is célszerú árnyaltabban megközelíteni. Homburg és Fargel (2007) empirikus kutatásokkal igazolják, hogy egyes iparágakban, egyes piacokon, bizonyos időintervallumokban az ügyfélmegtartás nem olyan jövedelmező, mint a folyamatos akvizíció. Ebből következik, hogy - jóllehet az ügyfélmegtartásra gondot kell fordítani - ,,a sikeres ügyfél-akvizíció jelentôs mértékben járulhat hozzá a nyereséges növekedéshez" (Homburg - Fargel, 2007, p. 57.). Saját kutatásaink is azt támasztják alá, hogy a tranzakciós és a kapcsolati preferenciák erősen szituáció-, ügyleti fázis- és partnerfüggőek, azaz egy adott piaci szereplő gyakorlatában is folyamatosan keverednek (Veres, 2007).

\section{A modellek}

A kutatások mellékterméke és egyes esetekben újszerú eredménye a modell. Utóbbiak közül egyesek mérföldkövekké válnak a tudományterület történetében, ahogy az a business marketingre is jellemző. Piskóti István tanulmánya is közöl olyan modelleket, melyek az általánosítás igényével születtek. Ilyen a Hadjikhani-LaPlaca-féle fejlődési modell, Möller modelljei, Kleinaltenkamp és Plinke versenyelóny modellje és nem utolsó sorban a tanulmány integrált business marketing modellje.

Különösképpen az IMP-iskola dolgozott ki szemléletes és jól általánosítható modelleket. Ilyen David Ford businessmarketing-alapmodellje (2002), amely a megbízó-megbízott kapcsolatban az aktorok által észlelhető bizonytalanságokat (uncertainties) és az ezeket enyhíteni képes szervezeti képességeket (capacities) állítja szembe. Jóllehet az észlelt kockázat (perceived risk) a tranzakciók egyik alapkategóriája, a modell szándékosan választja a bizonytalanságot, mint a kockázatérzet egyik determinánsát. Ezzel a megbízott és a megbízó minden olyan (eló)érzete számba vehetó, amely az ügylet sikeres teljesítését megkérdőjelezi, de nem mérhető fel olyan pontossággal, mint a kockázat. Rindfleisch és Heide (1997) megfogalmazásában a bizonytalanságok abból erednek, hogy „a (transzfer) körülményeit (t.i. a tényezók nagy számossága és korlátozott előre jelezhetósége miatt) nem lehet ex ante specifikálni” (i.m. 31).

David Ford modellje a szállító és a vevő képességeiról és bizonytalanságairól az egyedi technológia-transzferügyletek számos marketingsajátosságát súríti magába, egy olyan dinamikus felfogásban, ami a projektciklus lefutásához is illeszkedik (Ford, 2003, p. 42.). A Ford-modell szerint a szervezetközi tranzakciók a partnerek interaktív kommunikációját igénylik, mert a jó tervezéshez és a jó teljesítéshez egymás megértésén keresztül vezet az út. A képességek üzenete tudja moderálni a másik fél bizonytalanságait (Veres - Sajtos, 2011, 2012; Veres, 2012). Hangsúlyozni kell, hogy a projektüzletágban a legsúlyosabb kockázatelem a szállító komplett eredményfelelóssége, azaz az a kötelezettség, hogy a sikeres teljesítés összes feltételének számbavétele a szállító feladata. A komplett eredményfelelősség a teljesítményigazolás befejezéséig fennálló kockázati tényező, és ebből származtathatjuk a teljesítés kétoldalú (bilaterális) eredménykockázatát (Veres - Buzás, 2006; Veres, 2009).

\section{Összegzés}

Egy tudományterület lehatárolása nem lehetséges klasszifikációk - helyenként dichotómiák - konstruálása és differentia specifica-k meghatározása nélkül. 
Emellett számos esetben kontinuumjelleggel pontosabban tudjuk leírni a vonatkozó tudományterület kategóriáinak egymáshoz képesti viszonyát. A business marketing ilyen lehatárolására tesz üdvözlendő kísérletet Piskóti István saját kutatási eredményeket is felsorakoztató tanulmánya. A téma jelentőségét az is aláhúzza, hogy a business marketingtudomány a business marketinget egyébként intuitív módon sikeresen múvelők számára is tud még újat mondani. Szemléletben és gyakorlatban egyaránt.

\section{Lábjegyzet}

${ }^{1}$ A projektmarketingben ilyen volt a DUC-modell bevezetése (Mandják Veres, 1998)

\section{Felhasznált irodalom}

Backhaus, K. (1982): Investitionsgüter-Marketing. München: Vahlen

Cova, B. - Salle, R. (1999): Le Marketing d'Affaires. Paris: Dunod

Ford, D. (ed.) (2002): The Business Marketing Course Managing in Complex Networks. Chichester: Wiley

Ford, D. (szerk.) (2003): Business marketing. Budapest: KJK-KERSZÖV

Gross, A. - Banting, P. - Meredith, L. - Ford, D. (1993): Business Marketing. Boston: Houghton Mifflin

Gummesson, E. (1995): Relationsmarknadsföring: Från 4P till 30R. Malmö: Liber-Hermods

Homburg, Ch. - Fargel, T. (2007): Szisztematikus ügyfélszerzés. Harvard Business manager, május: p. 55-65.

Hunt, S. D. (2013): A general theory of business marketing: R-A theory, Alderson, the ISBM framework, and the IMP theoretical structure. Industrial Marketing Management, 42: p. 283-293.
Mandjak, T. - Veres, Z. (1998): The D-U-C Model and the Stages of Project Marketing Process. in: Halinen-Kaila, A. - Nummela, N. (eds.): Visions for the future, IMP Proceedings, Turku, Vol. 1: p. 471-490.

Michel, D. - Salle, R. - Valla, J.-P. (1996): Marketing industriel. Paris: Economica

Rindfleisch, A. - Heide, J. B. (1997): Transaction Cost Analysis: Past, Present, Future Applications. Journal of Marketing, 61(4): p. 30-54.

Vargo, S. L. - Lusch, R. F. (2004): Evolving to a New Dominant Logic for Marketing. Journal of Marketing, 68(1) : p. 1-17.

Veres, Z. - Buzas, N. (2006): Management des risques bilatéraux dans le transfert de technologie. La Revue du Management Technologique, PUG, Grenoble, 15(2): p. 47-74.

Veres, Z. (2007): „A kockázat megmarad, csak az érzet változik" - Tranzakciós és kapcsolati preferenciák a projekttípusú üzleti szolgáltatások piacán. Vezetéstudomány, XXXVIII. évf., 9. sz.: p. 51-64.

Veres, Z. (2009): Competence-based risk perception in the project business. Journal of Business and Industrial Marketing, Special Issue, 24(3/4): p. 237244.

Veres, Z. - Sajtos, L. (2011): Észlelt kockázat, észlelt érték és projekt-kompetenciák. Vezetéstudomány, XLII. évf., 1. sz.: p. 41-51.

Veres, Z. - L. Sajtos (2012): Competencias y Gestión de Riesgos de los Actores de Proyectos; Revista Internacional Administración \& Finanzas, The IBFR, Hilo (HI), 5(4): p. 51-62.

Veres, Z. (2012): Uncertainty-reducing project-competences as organizational capabilities; The IMP Journal, Vol. 6, Issue 2: p. 154-166. 